\title{
Brucellosis Presenting as Piriformis Abscess
}

\author{
Piriformis Apsesi ile Prezente Olan Brusella Olgusu \\ Fatih Bağcıer, Osman Onaç*, Ayhan Kul, Akın Erdal \\ Atatürk University Faculty of Medicine, Department of Physical Medicine and Rehabilitation, Erzurum, Turkey \\ * Metin Sabancı Baltalimanı Bone Diseases Training and Research Hospital, Clinic of Orthopedics and Traumatology, Istanbul, Turkey
}

\section{To the Editor;}

A 27-year-old man presented to our emergency department complaining of left hip pain. Our patient had been in excellent health until pain developed three days before his presentation. He had no history of tobacco use, alcohol use, intravenous drug use, or any other factors for HIV infection. Our patient's medical history was unremarkable. A physical examination revealed painful hip movement and a positive straight leg raise sign, without any other significant abnormalities. Further investigation was deemed necessary and our patient was subsequently admitted to the hospital. Results of a hip X-ray were unremarkable. Laboratory tests revealed a white blood cell count of 12.500 cells $/ \mathrm{mm}^{3}$ (normal 4.000 to 11.000 cells $/ \mathrm{mm}^{3}$ ) with $60 \%$ neutrophils (normal $50 \%$ to $70 \%$ ). He also had elevated inflammatory markers with erythrocyte sedimentation rate $90 \mathrm{~mm} / \mathrm{L}$ hour (normal: 0 to $20 \mathrm{~mm} / \mathrm{L}$ hour) and a C-reactive protein level of $11.16 \mathrm{mg} / \mathrm{dL}$ (normal: $<0.8 \mathrm{mg} / \mathrm{dL}$ ). His creatine phosphokinase level was $52 \mathrm{IU} / \mathrm{L}$ (normal: <190 IU/L) and lactate dehydrogenase level was $366 \mathrm{IU} / \mathrm{L}$ (normal 120 to $230 \mathrm{IU} / \mathrm{L}$ ). Specimens of blood and urine were obtained for culture. The same day, he was submitted to a computed tomography scan of the abdomen, which did not show any significant abnormality. A pelvic magnetic resonance imaging (MRI) scan was performed two days later. The examination revealed a markedly enlarged right piriformis muscle on the T1-weighted image (Figure 1). After gadolinium administration there was widespread pathological enhancement, consistent with the presence of myositis. Inflammatory changes were also depicted in the adjacent soft tissues, spreading along the fascial planes. Serology with a standard tube agglutination test revealed a titer of $>1 / 1280$ for $B$ melitensis. Two blood culture tests were also positive for $B$ melitensis. Antibiotic treatment for brucellosis was initiated, with doxycycline 100 mg twice daily, rifampin $900 \mathrm{mg}$ daily and ciprofloxacin $500 \mathrm{mg}$ twice daily. After six months of antibiotic treatment our patient was asymptomatic. At that time he was submitted to a follow-up MRI, which exhibited complete resolution of the previous findings. Our patient has remained asymptomatic to date. Myositis is a rare muscle infection, with the most commonly implicated bacteria being Staphylococcus and Streptococcus. Piriformis myositis has been rarely reported in the literature (1). Recognized predisposing factors for the condition are mainly previous viral or parasitic infections, rheumatic disease and human immunodeficiency virus infection. Piriformis pathology is a known but rare cause of hip pain and sciatica. This is due to its anatomic affinities, with the sciatic nerve closely related to the piriformis muscle, as it exits the pelvis through the greater sciatic notch. There have been reports of Brucella infection involving various unusual muscle groups

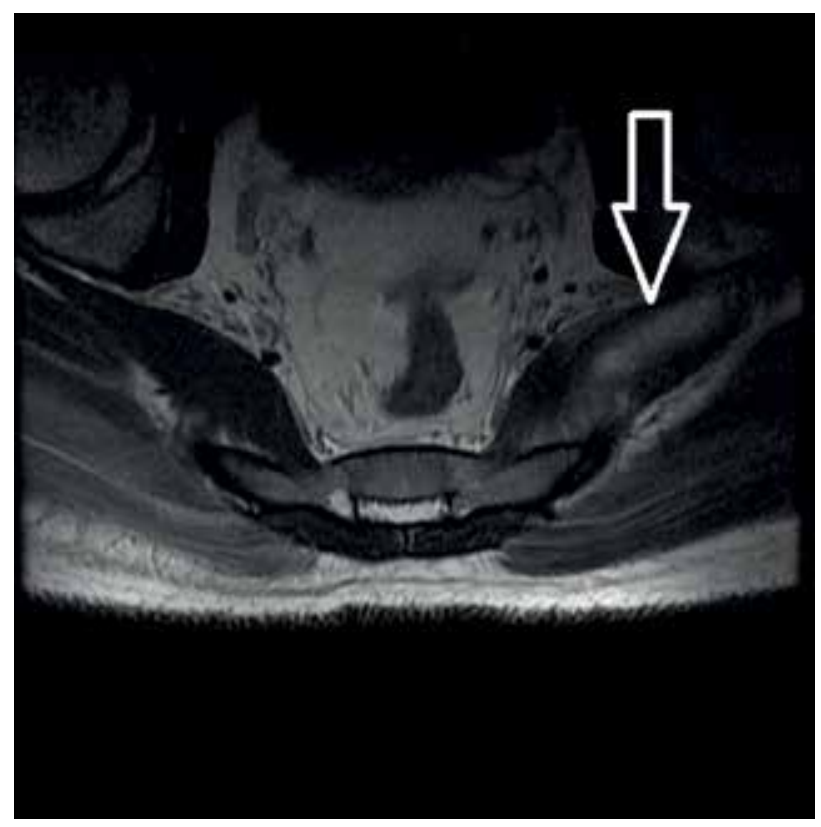

Figure 1. Enlarged right piriformis muscle on the T1-weighted image

Address for Correspondence/Yazışma Adresi: Fatih Bağcıer MD, Haydarpaşa Numune Training and Research Hospital, Clinic of Physical Medicine and Rehabilitation, İstanbul, Turkey Phone: +90 5056605754 E-mail: bagcier_42@hotmail.com Received/Geliş Tarihi: 19.12.2015 Accepted/Kabul Tarihi: 04.01.2016

${ }^{\circ}$ Copyright 2016 by Turkish Osteoporosis Society

Turkish Journal of Osteoporosis published by Galenos Yayınevi 
(2). However, involvement of the piriformis muscle in brucellosis, as first presentation, has not been previously reported in the literature.

Keywords: Myositis, muscle infection, Brucella melitensis

Anahtar kelimeler: Miyozit, kas enfeksiyonu, Brusella melitensis

\section{Ethics}

Peer-review: Internally peer-reviewed.

\section{Authorship Contributions}

Surgical and Medical Practices: Fatih Bağcıer, Osman Onaç, Ayhan Kul, Akın Erdal, Concept: Fatih Bağcıer, Osman Onaç,
Design: Ayhan Kul, Akın Erdal, Data Collection or Processing: Fatih Bağcıer, Analysis or Interpretation: Fatih Bağcıer, Literature Search: Fatih Bağcıer, Writing: Fatih Bağcıer.

Conflict of Interest: No conflict of interest was declared by the authors.

Financial Disclosure: The authors declared that this study received no financial support.

\section{References}

1. Chong KW, Tay BK. Piriformis pyomyositis: a rare cause of sciatica. Singapore Med J 2004;45:229-31.

2. Ozgocmen S, Ardicoglu A, Kocakoc E, Kiris A, Ardicoglu O. Paravertebral abscess formation due to brucellosis in a patient with ankylosing spondylitis. Joint Bone Spine 2001;68:521-4. 